\title{
Subsurface zones in intermittent streams are hotspots of microbial decomposition during the non-flow period
}

\author{
Rebeca Arias-Real ${ }^{\mathrm{a}, *}$, Isabel Muñoz a ${ }^{\text {, Cayetano Gutierrez-Cánovas }}{ }^{\mathrm{a}, \mathrm{b}, \mathrm{c}}$, Verónica Granados a \\ Pilar Lopez-Laseras a , Margarita Menéndez ${ }^{\text {a }}$ \\ a Department of Evolutionary Biology, Ecology and Environmental Sciences, Faculty of Biology, Universitat de Barcelona, Barcelona, Spain. \\ b Centre of Molecular and Environmental Biology (CBMA), Department of Biology, University of Minho, Campus of Gualtar, 4710-057 Braga, Portugal. \\ ${ }^{c}$ Institute of Science and Innovation for Bio-Sustainability (IB-S), University of Minho, Campus of Gualtar, 4710-057 Braga, Portugal.
}

\section{H I G H L I G H T S}

- Subsurface zone contributes to maintain decomposition during non-flow periods

- Surface decay rates decrease with intermittency more strongly compared to subsurface

- Subsurface fungal biomass increases with intermittency until saturation

- Phosphorus availability and fine sand content accelerate microbial decomposition

\section{G R A P H I C A L A B S T R A C T}
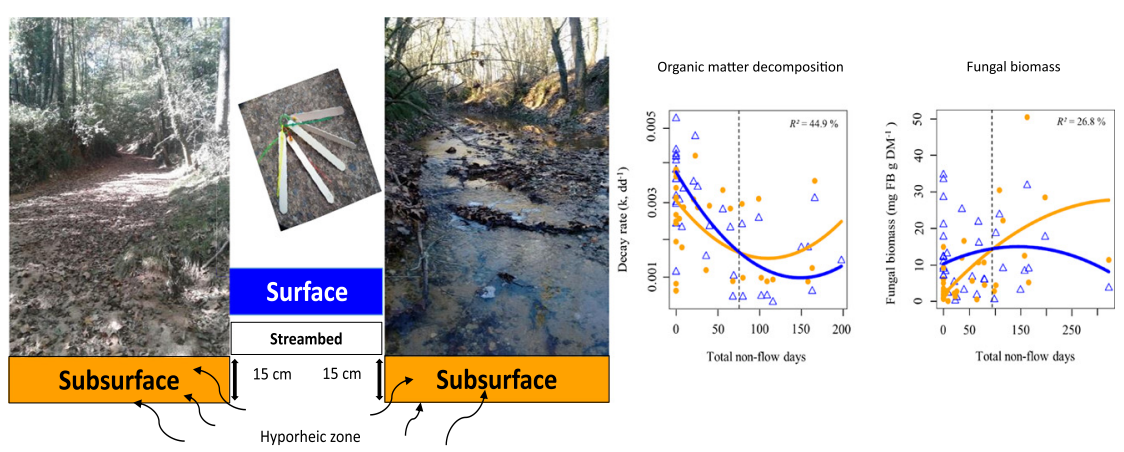

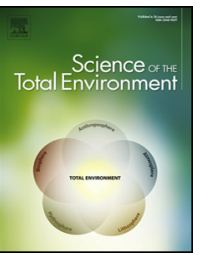




\section{Introduction}

Organic matter (OM) decomposition is a key ecosystem process that has implications for aquatic food webs and biogeochemical cycles, such as C-cycling pathways (Follstad Shah et al., 2017; Gessner et al., 1999). In forest streams, the main source of OM comes from riparian vegetation, such as leaf litter or woody debris; thus, both represent an essential energy source for food webs (Abril et al., 2016; Gonçalves et al., 2014). Microbes (fungi and bacteria) and invertebrates are the most important organisms that contribute to OM decomposition, but their activities may vary with local environmental conditions (Gessner et al., 2010). In freshwaters, fungi are the first colonisers and the main microbial decomposers during the early stages of decomposition, constituting an essential trophic link between OM and invertebrate consumers (AriasReal et al., 2018; Gessner and Chauvet, 1994; Kuehn, 2016). Aquatic OM decomposition depends on environmental factors that affect biological activity and/or physical degradation (Krauss et al., 2011). Recent evidence has shown that OM decomposition can be compromised in streams that experience periods of complete flow disruption in time or space (termed intermittent and ephemeral streams, IRES) (Datry et al., 2011, 2014, 2018; Larned et al., 2010) due to abrupt changes in environmental conditions (Foulquier et al., 2015; Lake, 2003). For instance, surface water loss reduced dissolved oxygen and increased water temperature, nutrients and conductivity (Krauss et al., 2011); it is also expected to reduce the richness and activity of aquatic decomposers (Gonçalves et al., 2016; Martínez et al., 2015). In addition, flow reduction affects the riparian vegetation, causing early leaf abscission (Sanpera-Calbet et al., 2016). This may lead to temporal and spatial changes in OM sources for microbes and invertebrates.

During the non-flow period, the subsurface zone could be particularly important in maintaining decomposition of OM because it is the last remaining habitat where water is available (Arce et al., 2019). In these conditions, microorganisms seek refuge by moving vertically into this zone (Stubbington, 2012). Moreover, non-flow favours OM (leaf litter and woody debris) accumulation in the dry streambed, which could be buried during storms (Scott and Zhang, 2012), leading the subsurface zone to become the major OM storage compartment in the stream (Cornut et al., 2012; Storey et al., 1999). As such, the subsurface zone could operate as an active zone during the non-flow period (Boulton et al., 1899, 1998; Marxen et al., 2010; Stubbington, 2012). However, it remains unclear whether the subsurface zone can support similar or higher rates of OM decomposition compared to the wet surface zone when flow is present.

Previous studies have shown the resilience of bacterial communities located in the subsurface zone to long-term non-flow periods when flash storms suddenly increase the water content in the sediment, which has implications for the maintenance of nutrient cycling and OM decomposition (Harjung et al., 2019; Marxen et al., 2010; Pohlon et al., 2013). While it is known that fungal communities are crucial for OM decomposition in the surface zone, there is still limited knowledge about their role in the subsurface zone; they might be essential for the sustainability of this process in the absence of surface water (Cornut et al., 2010, 2014).

However, flow intermittence may exert different effects on aquatic decomposers depending on the length and frequency of non-flow phases and the characteristics of different stream microhabitats (Burrows et al., 2017; Solagaistua et al., 2016). For example, aquatic life can persist during the non-flow phase in isolated pools, wet sediments and the hyporheic zone, but the suitability of these microhabitats could vary with grain size, solar irradiance or weather (Datry et al., 2011; Harjung et al., 2019; Marxen et al., 2010; Pohlon et al., 2013; Stubbington, 2012). In addition, some flash storms can rapidly stimulate and restore microbial activity (Barnard et al., 2015; Blazewicz et al.,
2014; Gionchetta et al., 2019). Therefore, considering that IRES represent approximately half of the global river network and that their spatial extent is expected to increase due to climate change and increased water use (Datry et al., 2017), there is an urgent need to better understand which hydrological, microhabitat and local environmental factors can sustain OM decomposition during the non-flow period.

The objective of this study was to explore the dynamics of microbial decomposition in the surface and subsurface zones of 20 streams, over a gradient of flow intermittency. First, we explored the effects of hydrology and microhabitat (surface and subsurface zones) on OM decomposition and fungal biomass, and then we analysed the effects of hydrological and environmental features on OM decomposition and fungal biomass in each zone separately. We hypothesised that (i) the rates of OM decomposition and the fungal biomass would be higher in the subsurface zone compared to the surface zone when intermittency increases, which would sustain OM processing, and (ii) the environmental features would modulate hydrological effects on OM decomposition through changes in the microbial communities (e.g., fungal biomass).

\section{Methodology}

\subsection{Study area}

This study was conducted in 20 low-order streams that belong to eight different basins across Catalonia (NE Spain). Forest, scrubland and grasslands were the primary land use at the riparian scale (Table 1). Although, in some streams, the main land use was extensive agriculture (mainly olive groves and vineyards), causing minor levels of anthropogenic impact (Corine Land Cover 2006 data from a buffer area of $1 \mathrm{~km}$ around each sampling site) (Table 1). Furthermore, poplar (Populus nigra L.), alder (Alnus glutinosa (L.) Gaertner) and evergreen oak (Quercus ilex L.O) were the dominant riparian vegetation. The climate is typically Mediterranean with dry and warm summers, and precipitation occurring mainly during spring and autumn.

\subsection{Stream hydrology}

We calculated the total number of non-flow days (TNF) at each site (Fig. 1). To do this, we used the daily variation of the streambed temperature as an indicator of water presence in lotic and lentic habitats. This daily variation was determined as the difference between the maximum and minimum temperatures on each day and the highest daily rate of change per hour. Temperature and water level were recorded with Leveloggers (Solinst Levelogger Edge, full-scale reading precision of $0.05 \%$ ) that were placed on the streambed (Constantz et al., 2001). The Leveloggers operated at hourly intervals for one year (study period from September 2016 until September 2017). The recorded data were corrected for atmospheric pressure variations using data from Barologgers (Solinst Barologger, full-scale reading precision of $0.05 \%$ ) that were installed at the riparian zone of each sampling site.

Once temperature data were retrieved, we performed a moving average of order 5 to smooth daily differences. We standardised each value with a fixed value per month, using data from field observations, data from the meteorological stations (Servei Meteorològic de Catalunya; http://www.meteocat.es) at each site (or nearby), and the water level data from the Leveloggers. Furthermore, we corrected the occasional similarity between streambed temperature and air temperature during autumn and spring with precipitation data from meteorological stations. 
t1.1 Table 1

t1.2 Geographical and basin characterization of the studied sites. The percentages of land use cover refer to a buffer area of $1 \mathrm{~km}$ around each sampling point.

\begin{tabular}{|c|c|c|c|c|c|c|c|c|c|c|}
\hline \multirow[t]{2}{*}{ Site } & \multirow[t]{2}{*}{ Lat., $\mathrm{N}$} & \multirow[t]{2}{*}{ Long., E } & \multirow[t]{2}{*}{ Altitude (m.a.s.l) } & \multirow[t]{2}{*}{ Order } & \multirow[t]{2}{*}{ Basin } & \multirow[t]{2}{*}{ Prec. (mm) } & \multirow[t]{2}{*}{ Catchment area $(\mathrm{km} 2)$} & \multicolumn{3}{|c|}{ Land Use Cover (\%) } \\
\hline & & & & & & & & Urban & Agric. & Nat. \\
\hline 1 & $41^{\circ} 46^{\prime} 14.72^{\prime \prime}$ & $2^{\circ} 16^{\prime} 9.39^{\prime \prime}$ & 430 & 3 & $\mathrm{BE}$ & 788 & 6.5 & 2.2 & 0.7 & 97.1 \\
\hline 2 & $42^{\circ} 7^{\prime} 28.68^{\prime \prime}$ & $2^{\circ} 26^{\prime} 27.30^{\prime \prime}$ & 484 & 4 & $\mathrm{FL}$ & 1026 & 15.7 & 0 & 1.1 & 98.9 \\
\hline 3 & $42^{\circ} 7^{\prime} 30.84^{\prime \prime}$ & $2^{\circ} 40^{\prime} 54.96^{\prime \prime}$ & 219 & 4 & $\mathrm{FL}$ & 998 & 13.8 & 0 & 34.4 & 65.6 \\
\hline 4 & $42^{\circ} 6^{\prime} 50.94^{\prime \prime}$ & $2^{\circ} 26^{\prime} 53.16^{\prime \prime}$ & 475 & 4 & $\mathrm{FL}$ & 475 & 965.4 & 0.1 & 2.8 & 97.1 \\
\hline 5 & $42^{\circ} 10^{\prime} 28^{\prime \prime}$ & $2^{\circ} 28^{\prime} 71^{\prime \prime}$ & 434 & 3 & $\mathrm{FL}$ & 963 & 6.7 & 0 & 0 & 100 \\
\hline 6 & $41^{\circ} 23^{\prime} 51.64^{\prime \prime}$ & $1^{\circ} 35^{\prime} 36.94^{\prime \prime}$ & 330 & 4 & FO & 590 & 26.9 & 0 & 100 & 0 \\
\hline 7 & $41^{\circ} 24^{\prime} 41.89^{\prime \prime}$ & $1^{\circ} 35^{\prime} 36.65^{\prime \prime}$ & 390 & 3 & FO & 574 & 1.8 & 0 & 96.4 & 3.6 \\
\hline 8 & $41^{\circ} 18^{\prime} 36.43^{\prime \prime}$ & $1^{\circ} 5^{\prime} 16.00^{\prime \prime}$ & 605 & 4 & FR & 470 & 28.9 & 0 & 14.1 & 85.9 \\
\hline 9 & $41^{\circ} 44^{\prime} 28.38^{\prime \prime}$ & $1^{\circ} 56^{\prime} 9.94^{\prime \prime}$ & 325 & 3 & LL & 732 & 10.9 & 2.2 & 0.9 & 96.9 \\
\hline 10 & $41^{\circ} 37^{\prime} 57.88^{\prime \prime}$ & $1^{\circ} 55^{\prime} 55.87^{\prime \prime}$ & 394 & 3 & LL & 692 & 8.6 & 0 & 0 & 100 \\
\hline 11 & $41^{\circ} 34^{\prime} 53.82^{\prime \prime}$ & $1^{\circ} 59^{\prime} 5.52^{\prime \prime}$ & 335 & 4 & LL & 635 & 23.9 & 1.2 & 2.9 & 95.9 \\
\hline 12 & $42^{\circ} 23^{\prime} 15.58^{\prime \prime}$ & $3^{\circ} 3^{\prime} 6.24^{\prime \prime}$ & 100 & 3 & MU & 842 & 13.5 & 0 & 99.5 & 0.5 \\
\hline 13 & $42^{\circ} 6^{\prime} 35.35^{\prime \prime}$ & $2^{\circ} 29^{\prime} 19.30^{\prime \prime}$ & 526 & 3 & $\mathrm{TE}$ & 963 & 13.3 & 0 & 0.6 & 99.4 \\
\hline 14 & $42^{\circ} 4^{\prime} 40.59^{\prime \prime}$ & $2^{\circ} 20^{\prime} 19.44^{\prime \prime}$ & 630 & 4 & TE & 953 & 30.9 & 1.5 & 0 & 98.5 \\
\hline 15 & $41^{\circ} 55^{\prime} 12.78^{\prime \prime}$ & $2^{\circ} 42^{\prime} 51.23^{\prime \prime}$ & 140 & 3 & TE & 816 & 7.7 & 0 & 78.5 & 21.5 \\
\hline 16 & $42^{\circ} 4^{\prime} 17.73^{\prime \prime}$ & $2^{\circ} 32^{\prime} 26.86^{\prime \prime}$ & 385 & 3 & $\mathrm{TE}$ & 1038 & 9.1 & 0 & 0.9 & 99.1 \\
\hline 17 & $41^{\circ} 42^{\prime} 33.64^{\prime \prime}$ & $2^{\circ} 32^{\prime} 2.87^{\prime \prime}$ & 110 & 3 & TO & 865 & 49.1 & 0 & 0.6 & 99.4 \\
\hline 18 & $41^{\circ} 49^{\prime} 23.01^{\prime \prime}$ & $2^{\circ} 27^{\prime} 9.01^{\prime \prime}$ & 489 & 3 & TO & 911 & 12.4 & 0 & 0.2 & 99.8 \\
\hline 19 & $41^{\circ} 51^{\prime} 57.91^{\prime \prime}$ & $2^{\circ} 35^{\prime} 35.04^{\prime \prime}$ & 655 & 4 & TO & 875 & 49.0 & 0 & 0 & 100 \\
\hline 20 & $41^{\circ} 52^{\prime} 42.10^{\prime \prime}$ & $2^{\circ} 38^{\prime} 54.46^{\prime \prime}$ & 170 & 3 & TO & 908 & 12.4 & 0.8 & 3.3 & 95.9 \\
\hline
\end{tabular}

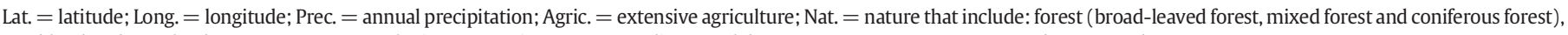
scrubland and grasslands; $\mathrm{BE}=$ Besos; FL $=$ Fluvia; FO = Foix; FR $=$ Francoli; $\mathrm{LL}=$ Llobregat; $\mathrm{MU}=\mathrm{Muga}$;E $=\mathrm{Ter}$ and $\mathrm{TO}=\mathrm{Tordera}$.

\subsection{Environmental factors}

For each stream location, we performed three sampling campaigns: the first (t0) during September/October 2016, the second (t1) during February 2017 and the third (t2) during September 2017. At each time and location, we measured water electrical conductivity, water temperature, $\mathrm{pH}$ and dissolved oxygen $\left( \pm 1 \mu \mathrm{sm}^{-1}, \pm 0.1^{\circ} \mathrm{C}, \pm 0.005\right.$ $\mathrm{pH}$ and $\pm 0.1 \mathrm{mg} \mathrm{L}^{-1}$, respectively) using a portable probe (YSI Professional Plus Multiparameter Instrument, USA).

To characterise the nutrient concentrations in the water (nitrite, nitrate, ammonium and soluble reactive phosphorus (SRP)), we took water samples when surface water was present. Water samples were filtered through pre-combusted glass fibre filters in the field $(0.7 \mu \mathrm{m}$ pore size; Whatman GF/F, Germany) and then transported to the laboratory under cooled conditions. In the laboratory, we stored the water samples at $4{ }^{\circ} \mathrm{C}$, in darkness, until analysis (between 24 and $48 \mathrm{~h}$ ).
We analysed the concentrations of dissolved nitrite $\left(\mathrm{NO}_{2}^{-}\right)$and nitrate $\left(\mathrm{NO}_{3}^{-}\right)$using ionic chromatography with a conductivity detector WATERS (model 432), UV/V KONTROL detector (model 332) and the column WATER IC-PAK ANIONS (Metrohm 761 Compact IC with the column Metrosep A Supp5 - 150/4.0). We measured the ammonium concentration using the salicylate method (Reardon et al., 1969) and SRP using the molybdate method (Murphy and Riley, 1962).

To characterise the sediment, we used a shovel and took three replicates per stream from the top $0-5 \mathrm{~cm}$ and down to $16 \mathrm{~cm}$ deep in the same habitat where had placed the wood sticks, to be sure that it did not skew the results by spatial variation of the streams. The samples were placed into jars and transferred to the laboratory under conditions of darkness. In the laboratory, one aliquot of fresh sediment was allotted for granulometric analysis, and a second aliquot was dried at $70^{\circ} \mathrm{C}$ until it reached a constant weight for dry weight determination and elemental analysis.

To determine the grain size distribution, fresh sediment samples (first aliquot) were first treated with $\mathrm{H}_{2} \mathrm{O}_{2}$ (10\% volume) to remove

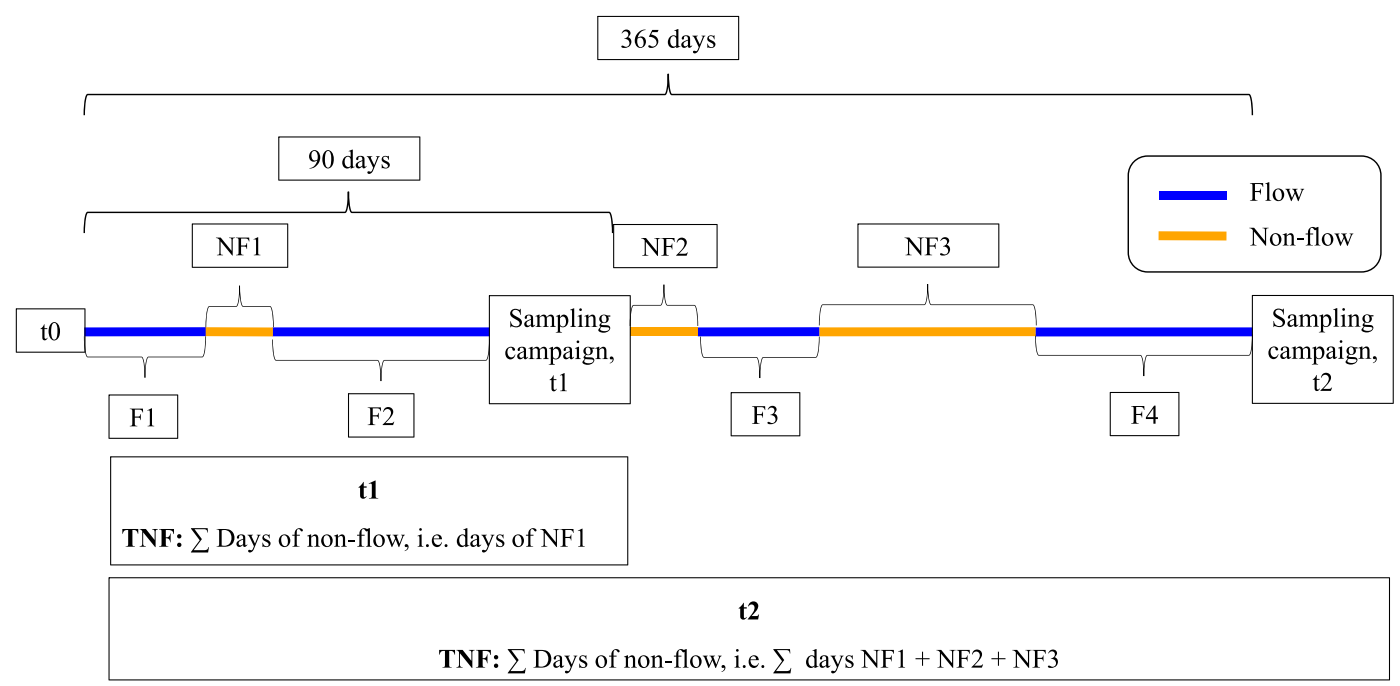

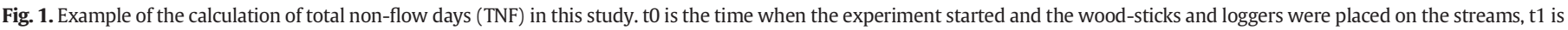

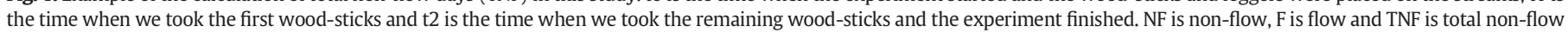
days. 
organic matter and later disaggregated and dispersed ultrasonically with pyrophosphate. Fractions up to $2 \mathrm{~mm}$ were determined by sieving, while the determination of fractions below $2 \mathrm{~mm}$ was performed with a Beckman-Coulter LS230 laser. Then, the dry material (second aliquot) was ground using an agate mortar until it was completely homogenised, and we analysed the nitrogen $(\mathrm{N})$ and carbon $(\mathrm{C})$ concentrations using a Thermo Elemental Analyser 1108 (Thermo Scientific, Milan, Italy). We expressed the results in terms of $\mathrm{C}: \mathrm{N}$ molar ratios.

The water sediment content or moisture content was calculated as the percentage of water loss (\%), which was determined by the difference between fresh and dry weight.

\subsection{Organic matter experiment}

We quantified the decomposition of OM in both surface and subsurface zones using sticks of Populus canadensis wood $(15 \times 2 \times 0.2 \mathrm{~cm})$ (Arroita et al., 2012). We placed 10 sticks on the streambed to characterise surface decomposition and 10 sticks at a depth of $15 \mathrm{~cm}$ below the streambed to quantify subsurface decomposition. The sticks were placed in each stream at $t 0$. Before being placed in the streams, the sticks were marked, oven-dried $\left(70^{\circ} \mathrm{C}, 72 \mathrm{~h}\right)$ and weighed. In the surface zone, each group of sticks was tied to metal bars with nylon threads, branches or roots to ensure that it remained in the lotic habitat. During flowing periods, we ensured that the sticks were completely submerged. In the subsurface zone, each group of sticks was inserted into the sediment and tied to metal bars with nylon thread. An extra set of 20 sticks per stream was transported but not placed in the streams and then returned to the laboratory to correct the initial weight, taking account of manipulation. These sticks were used to calculate the initial dry mass and ash content.

The sticks that were placed in the streams were picked up during the two sampling campaigns: one after between 90 and 100 days ( $\mathrm{t} 1$ ) and the second after one year ( $\mathrm{t} 2$ ). During each sampling, we collected five sticks per zone (half of the sticks). The sticks were placed in individual zip-lock bags and transported to the laboratory in refrigerated containers.

Once in the laboratory, we processed the sticks immediately to avoid changes in weight and ergosterol degradation. First, we gently brushed them to remove adhering material and then washed them with distilled water. Afterwards, we cut and weighed one $1-\mathrm{cm}$-long aliquot of each stick. These aliquots were frozen at $-80{ }^{\circ} \mathrm{C}$ for later determination of the ergosterol concentration as a proxy for fungal biomass (Gessner, 2005). Then, the remaining part of each stick was dried $\left(70^{\circ} \mathrm{C}, 72 \mathrm{~h}\right.$ ) and weighed to calculate the final dry mass.

We cut two 1-cm-long aliquots from the remaining dry part for subsequent analysis. The first aliquot was incinerated $\left(500^{\circ} \mathrm{C}, 5 \mathrm{~h}\right)$ to measure the ash-free dry mass (AFDM) by removing inorganic components, and the second aliquot was used to analyse the nitrogen $(\mathrm{N})$ and carbon (C) content.

To analyse the ergosterol concentration as a proxy of fungal biomass (Gessner, 2005), an aliquot of each stick was lyophilized and weighed to determine the dry mass, and lipid extraction and saponification were performed using $0.14 \mathrm{M} \mathrm{KOH}$ methanol $\left(8 \mathrm{~g} \mathrm{~L}^{-1}\right)$ at $80^{\circ} \mathrm{C}$ for $30 \mathrm{~min}$ in a shaking water bath. The extracted lipids were purified using solidphase extraction cartridges (Waters Sep-Pak ${ }^{\circledR}$ Vac RC, 500 mg tC18 cartridges, Waters Corp, Milford, MA, USA), and ergosterol was eluted using isopropanol. We used high-pressure liquid chromatography (HPLC) to detect and quantify the ergosterol by measuring the absorbance at $282 \mathrm{~nm}$. We used a Jasco HPLC system (USA) equipped with a Gemini-NX $5 \mu \mathrm{m} \mathrm{C18} 250 \times 4.6 \mathrm{~mm}$ column (Phenomenex, UK). The mobile phase was $100 \%$ methanol, and the flow rate was set to $1.2 \mathrm{ml} \mathrm{min}{ }^{-1}$. Finally, we converted the ergosterol measurement into fungal biomass using a conversion factor of $5.5 \mathrm{mg}$ of ergosterol per gram of fungal mycelium (Gessner and Chauvet, 1993). We expressed the results in $\mathrm{mg}$ of fungal biomass per gram of dry mass.
To determine the $\mathrm{N}$ and $\mathrm{C}$ content in the sticks, the aliquots were ground and analysed with the same methodology used to analyse the $\mathrm{N}$ and $\mathrm{C}$ content in the sediment. We expressed the results in terms of $\mathrm{C}: \mathrm{N}$ molar ratios.

Finally, we estimated the decay rates following the negative exponential model $\mathrm{M}_{\mathrm{t}}=\mathrm{M}_{0} \mathrm{e}^{-\mathrm{kt}}$, where $\mathrm{M}_{0}$ is the initial percentage of AFDM, $M_{t}$ is the remaining AFDM at time $t$, and $k$ is the decay rate (Petersen and Cummins, 1974). We expressed the decay rates in terms of accumulated heat by replacing time with the mean daily temperatures accumulated (degree-days, $\mathrm{dd}^{-1}$ (Stout, 1989)). To express the decay rates in degree-days, we used the mean daily temperatures from the Leveloggers, and for the subsurface zone, we used the mean daily temperatures from the SmartButtons (ACR Systems Inc. data logger temperature recorders) that were placed in the subsurface zone (15 $\mathrm{cm}$ below the streambed) at $\mathrm{t} 0$.

\subsection{Data analysis}

To reduce distribution skewness, water sediment, coarse sand, DIN and SRP were log-transformed and clay, fungal biomass and C:N ratios of sediments were square-root-transformed, before the analyses were performed. All quantitative predictors were $Z$-standardised (mean $=$ $0, S D=1$ ) to allow for model coefficient comparison. To assess predictor collinearity, we estimated the Variance Inflation Factor (VIF; vifstep, usdm R package (Zuur et al., 2009, 2010)) and pairwise Pearson correlations (cut-off of $r \leq|0.70|$ ) (Feld et al., 2016). To analyse how OM decomposition (decay rates) and fungal biomass respond to flow intermittence at surface and subsurface zones, we used linear mixedeffect models (LMMs, lme4 R package (Pinheiro et al., 2017)). For both response variables, we created LMMs that included TNF, zone (twolevel qualitative predictor: surface and subsurface) and their interaction as fixed factors. These models included data from 20 sites, in which both surface and subsurface zones were surveyed on two occasions (decay rates: $n=70$; fungal biomass: $n=72$ ). Using Akaike Information Criteria (AIC) values, we checked two random structures ("sampling site" and "sampling site nested within basins") to account for nonindependent structures within samples belonging to the same sites and basins. We selected "sampling site" as the random structure for both decay rates and fungal biomass models, as this model structure showed a better explanatory capacity and model simplicity (lower AIC values). Furthermore, we used a quadratic term for TNF to account for nonlinear responses. For each LMM, we estimated the variance explained by the fixed factors alone $\left(r_{\mathrm{m}}^{2}\right)$ and the variance explained by both the fixed and the random terms $\left(r_{\mathrm{c}}^{2}\right)$. To explore the relative importance of TNF, zone (surface vs. subsurface) and their interactions in the models, we performed variance partitioning on LMMs using the variancePartition $\mathrm{R}$ package (Hoffman and Schadt, 2016).

To identify how environmental features modulate hydrological effects on OM decomposition and fungal biomass in surface and subsurface zones, we followed a two-step modelling procedure that included an exploratory analysis to select the most important predictors and final models to estimate environmental features importance and significance (Feld et al., 2016). These models included 20 sites surveyed on two occasions (surface zone: $n=38$ and subsurface zone: $n=36$ ).To rank and select predictors according to their predictive power, we used Spearman rank correlations to account for potential non-linear responses. Second, to quantify the effects, importance and significance of hydrology (TNF) and the best environmental predictors of OM decomposition (decay rates) and fungal biomass, we fitted linear regression models (LMs) and LMMs. Then, between these models, we selected linear mixed model (LMM) for decay rates on the surface zone and linear regression models (LMs) for decay rates on the subsurface zone and fungal biomass in both, surface and subsurface zones, due to their greater explanatory capacity and parsimony compared to LMMs (i.e., lower AIC values (Akaike, 1973)). 
In the surface zone models, for LMM of decay rates we used TNF, SRP, conductivity and their interaction as fixed factors and sampling site as random factor, to account for repeated measures in the same location. In the LM, we used TNF, SRP and conductivity as predictors for fungal biomass.

In the subsurface zone, we used TNF, fine sand, water sediment content and $\mathrm{C}: \mathrm{N}$ ratios of the sediment as predictors for decay rates in each LM, whereas we used TNF, coarse sand, water sediment content and C:N ratios of the sediment as predictors for fungal biomass in each LM. None of the final input variables included in the final models has a collinearity problem (Table S1).

To explore the relative importance of hydrology (TNF) and the best environmental predictors into the models, we performed variance partitioning on LMM and LMs using the variancePartition R package (Hoffman and Schadt, 2016).

All models were validated by visually checking their residuals for normality and homoscedasticity (Zuur et al., 2010). All statistical analyses were performed using the R statistical software version 3.4.1 with the significance level set at $p<.05$ for all tests ( $R$ Development Core Team, 2011) (for more details see S2_Rscripts.zip).

\section{Results}

The studied streams covered a steep gradient of intermittency (from permanent to ephemeral streams) (Table S3). Dissolved oxygen varied from $4.9 \mathrm{mg} \mathrm{L}^{-1}$ to $9.2 \mathrm{mg} \mathrm{L}^{-1}$, conductivity varied from $164.6 \mu \mathrm{S} \mathrm{cm}^{-1}$ to $827.0 \mu \mathrm{S} \mathrm{cm}{ }^{-1}$, DIN (nitrite + nitrate + ammonia) varied from $0.424 \mathrm{mg} \mathrm{L}^{-1}$ to $6.174 \mathrm{mg} \mathrm{L}^{-1}$ and SRP varied from $0.008 \mathrm{mg} \mathrm{L}^{-1}$ to $1.727 \mathrm{mg} \mathrm{L}^{-1}$ in surface flowing water (Table S4). Moisture content varied from $2 \%$ to $84 \%$; sediment grain size proportions varied from $0 \%$ to $19.31 \%$ clay, $0 \%$ to $48.21 \%$ silt, $0 \%$ to $32.98 \%$ fine sand, $9.72 \%$ to $98.75 \%$ coarse sand, and $0 \%$ to $61.95 \%$ gravel; and the ratios of C:N in the sediments varied from 9.1 to 186.8 (Table S5).

\subsection{Effects of hydrology and zone on OM decomposition and fungal biomass}

OM decomposition (decay rates, $\mathrm{k} \mathrm{dd}^{-1}$ ) and fungal biomass were greater in the subsurface zone compared to the surface zone when TNF increased (Table 2, Fig. 2), as reflected by the significant interactions between non-flow days and zone (Table 2).

The decay rates at the surface decreased with TNF more sharply than the subsurface decay rates, which even recovered at the most ephemeral sites (TNF $>100$ days). Thus, in streams with $<75$ days of nonflow, decay rates $\left(\mathrm{k}, \mathrm{dd}^{-1}\right)$ were higher in the surface zone (Mean \pm $\mathrm{SE} ; 0.0031 \pm 0.0002)$ than in the subsurface zone $(0.0025 \pm 0.0002)$. However, for streams experiencing $>75$ days of non-flow, decay rates

Table 2

Results of the LMMs relating decay rates, $\mathrm{k}\left(\mathrm{dd}^{-1}, \mathrm{n}=70\right.$ ) and fungal biomass ( $\mathrm{mg}$ FB $\mathrm{g}$ $\mathrm{DM}^{-1}, \mathrm{n}=72$ ) to TNF and zone and their interactions. Standardised effect size (SES), standard error (SE), significance and variance explained are shown. Significant variables are highlighted in bold. $\mathrm{r}_{\mathrm{m}}^{2}$ : variance explained by the fixed factor alone; $\mathrm{r}_{\mathrm{c}}^{2}$ : variance accounting for both fixed and random terms. The quadratic term $\left({ }^{2}\right)$ means that the response is nonlinear.

\begin{tabular}{clrlrllll}
\hline & $\begin{array}{l}\text { Hydrological } \\
\text { variables }\end{array}$ & \multicolumn{1}{l}{ SES } & SE & $p$-Value & $\begin{array}{l}\text { Explained } \\
\text { variance }\end{array}$ & $\mathrm{r}_{\mathrm{m}}^{2}$ & $\mathrm{r}_{\mathrm{c}}^{2}$ \\
\hline OM decay & Intercept & 0.003 & 0.001 & $<0.001$ & & 44.9 & 73.6 \\
rate, $\mathrm{k}$ & TNF & -0.001 & 0.000 & $<\mathbf{0 . 0 0 1}$ & 38.4 & & \\
$\left(\mathrm{dd}^{-1}\right)$ & Zone & 0.000 & 0.000 & 0.121 & 0.5 & & \\
& TNF x zone & -0.001 & 0.000 & $\mathbf{0 . 0 0 2}$ & 3.9 & & \\
& TNF & -0.001 & 0.000 & $\mathbf{0 . 0 3 2}$ & 1.8 & & \\
Fungal & Intercept & 1.627 & 0.341 & $<0.001$ & & 26.8 & 65.1 \\
Biomass & TNF & 1.194 & 0.206 & $<\mathbf{0 . 0 0 1}$ & 2 & & \\
$\left(\right.$ mg FB g $^{2}$ & Zone & 0.697 & 0.228 & $\mathbf{0 . 0 0 4}$ & 4.2 & & \\
DM $\left.^{-1}\right)$ & TNF x zone & -1.125 & 0.229 & $<\mathbf{0 . 0 0 1}$ & 21.1 & & \\
& TNF & 0.883 & 0.233 & $<\mathbf{0 . 0 0 1}$ & 11.1 & & \\
\hline
\end{tabular}

were higher in the subsurface zone $(0.0018 \pm 0.0003)$ than in the surface zone $(0.0014 \pm 0.0002)$ (Fig. 2a).

For streams with $<75$ days of non-flow, the contribution of decay rates (relative to the total decay rates, i.e., the sum of the decay rates in the surface and subsurface zones) in the surface zone was $10.23 \%$ higher than that in the subsurface zone. For streams with $>75$ days of non-flow, the contribution of decay rates in the subsurface zone was 9.77\% higher than that in the surface zone (Fig. 3a). Furthermore, as we observed in Fig. 3a, for the streams with $>75$ days of non-flow, the contribution of decay rates in the subsurface zone was only $0.32 \%$ less than the contribution of decay rates in the surface zone for the streams with $<75$ days of non-flow.

We showed that in the surface zone, fungal biomass hardly changes along the gradient of intermittency; nevertheless, in the subsurface zone, we showed that when the intermittency increases, the fungal biomass increases (Fig. 2b).

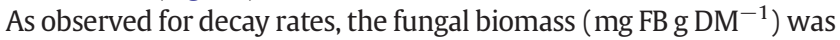
higher in the surface zone $(12.3 \pm 1.8)$ than in the subsurface zone $(4.9 \pm 0.9)$ in streams with $<90$ days of non-flow; however, after 90 days of non-flow, the fungal biomass was higher in the subsurface zone $(20.6 \pm 5.5)$ than in the surface zone $(13.9 \pm 3.2)$.

For streams with $<90$ days of non-flow, in the surface zone, the contribution of fungal biomass (relative to the total fungal biomass, i.e., the sum of the fungal biomass in the surface and subsurface zones) was $43.2 \%$ higher than that in the subsurface zone. For streams with $>90$ days of non-flow, the fungal biomass in the subsurface zone was $19.6 \%$ higher than that in the surface zone (Fig. 3b). Furthermore, as we observed in Fig. 3b, for the streams with $>90$ days of non-flow, the contribution of fungal biomass in the subsurface zone was $11.8 \%$ less than the ratio of fungal biomass in the surface zone for the streams with $<90$ days of non-flow.

Fixed factors (TNF and zone) explained $39.1 \%$ of the variance in decay rates and $25.6 \%$ of the variance in fungal biomass (Table 2 ). For decay rates, the variable that explained the most variance was TNF (38.4\%), whereas for fungal biomass, the interaction between TNF and zone was the most explanatory term (21.1\%).

\subsection{Effects of hydrology and environmental features on OM decomposition and fungal biomass}

The first exploratory analysis with Spearman rank correlations identified TNF, SRP concentration and water conductivity as the best predictors of decay rates and fungal biomass in the surface water $(n=38)$. In the subsurface zone, the best predictors were TNF, moisture content and $\mathrm{C}: \mathrm{N}$ ratios in the sediment $(n=36)$. Sediment grain size was also a good predictor for both response variables in the subsurface zone; fine sand was a good predictor for decay rates and coarse sand for fungal biomass.

In the surface zone, decay rates decreased when TNF increased but no other environmental predictor showed a significant effect (Table 3; Fig. 4a). In the subsurface zone, decay rates decreased when TNF increased, but the higher presence of fine sand was associated more with higher decay rates and higher moisture content than were lower decay rates with higher water loss (Table 3, Fig. 4b and c, respectively).

Fungal biomass in the surface zone decreased as TNF increased, but higher SRP was linked with higher fungal biomass (Fig. 4d). However, in the subsurface zone, fungal biomass increased as TNF increased, and the magnitude of this increase was related to sediment grain size; in the sites with a higher presence of coarse sand, the fungal biomass was lower (Fig. 4e). Furthermore, higher C:N content in the sediment was associated with lower fungal biomass (Fig. 4f).

\section{Discussion}

Overall, our findings confirm our hypothesis that subsurface processes had an important contribution to sustaining microbial decomposition during the non-flow periods of intermittent and ephemeral 
a)

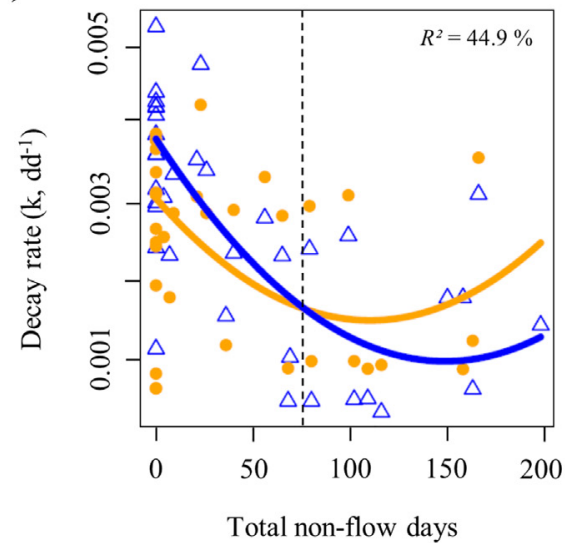

b)

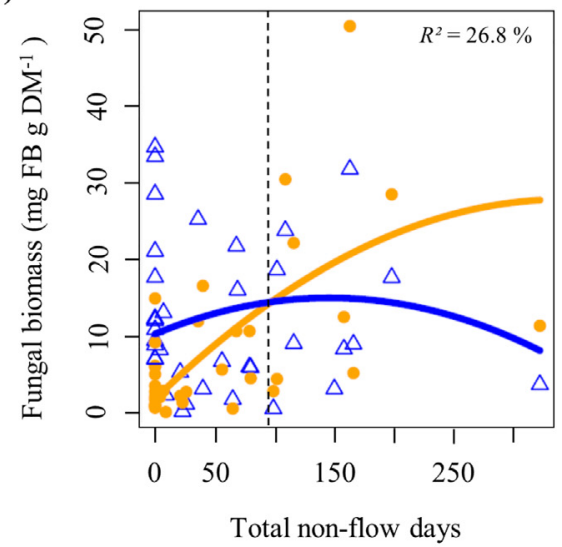

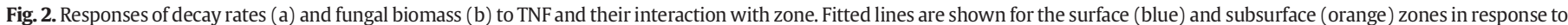

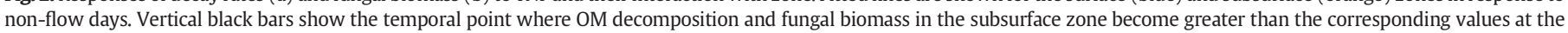
surface. (For interpretation of the references to colour in this figure legend, the reader is referred to the web version of this article.)

streams (IRES). We also showed that the magnitude of microbial decomposition and fungal biomass in the surface and subsurface zones depends on the local environmental factors of streams, such as SRP in the surface zone and sediment grain size, water content and sediment C:N ratio in the subsurface zone.

\subsection{Effects of hydrology and zone on OM decomposition and fungal biomass}

Previous research has shown that the duration of the non-flow period is a key factor in controlling microbial activity and OM decomposition (Bruder et al., 2011; Foulquier et al., 2015). However, thus far, most studies have focused on either the surface zone or the subsurface zone (Burrows et al., 2017; Corti and Drummond, 2011; Datry et al., 2018; Pinna and Basset, 2004), rather than simultaneously considering both zones. Nevertheless, our results demonstrate that simultaneously studying both zones is crucial to furthering our understanding of how microbial decomposition may respond to the expected increase in the duration and severity of flow intermittency as a result of climate change. In fact, although OM processing on both zones decreases with increased intermittency, the subsurface zone could maintain OM decomposition when the period without flow lengthens (Figs. 2a and 3a); for instance, streams with $>75$ days of non-flow could maintain approximately the same decomposition rates as the surface zones in streams with $<75$ days of non-flow.

The results of our study show how the increase in the number of non-flow days that is related to lower OM decomposition in the surface zone could be due to the decrease in fungal biomass (Mustonen et al., 2016). As previous studies have pointed out, flow disruption constrains and retards fungal growth and colonization because sporulation requires flowing water (Arias-Real et al., 2018; Duarte et al., 2017; Gessner et al., 2010). Additionally, this reduction in fungal biomass and activity coupled to changes in the initial chemical composition of OM (leaf litter and woody debris), affects the palatability of OM (Suberkropp et al., 1983). On the one hand, higher fungal biomass is related to an enrichment of nitrogen and phosphorus concentrations in the OM (Menéndez et al., 2011), and on the other hand, fungi transform recalcitrant polymers into more labile molecules, so their reduction due to flow disruption leads to a corresponding reduction in the quality of the OM (Bruder et al., 2011; Corti and Drummond, 2011; Solagaistua et al., 2016). This reduction in the quality of the OM affects aquatic invertebrates' consumption of OM (Gonçalves et al., 2014, 2016; Graça et al., 2001). The reductions in both fungal biomass and detritus quality seem to reduce OM decomposition in the surface zone, which is in line with previous studies (see for example (Bruder et al., 2011; Corti and Drummond, 2011; Costantini and Rossi, 2010)).

On the other hand, OM decay rates are higher in the subsurface zone than in the surface zone as the number of non-flow days increases, this could be due to fungal biomass in the subsurface zone increasing when the intermittency increases (Fig. 1b); therefore, the subsurface zone could potentially maintain OM decomposition during non-flow periods. This confirms our hypothesis that the subsurface zone is active over an intermittency gradient and reinforces the results of Burrows et al., (Burrows et al., 2017) who found a similar trend using a qualitative approach (permanent vs intermittent streams) in Australian streams.

Part of the explanation could be that the subsurface zone acts as a valuable refuge that maintains microbial activity, OM processing and a)

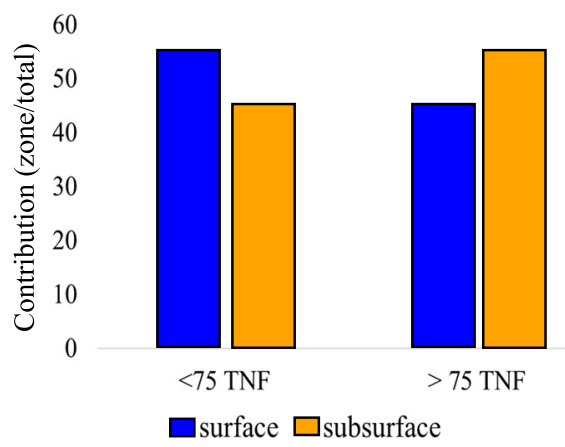

b)

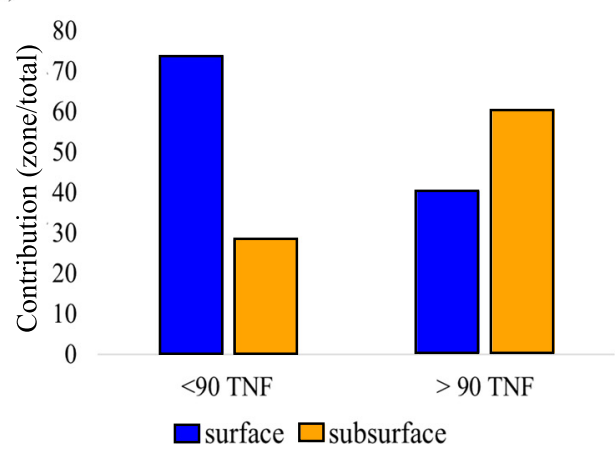

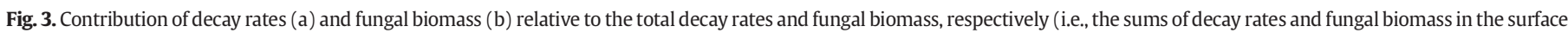
and subsurface zones). 
t3.1 Table 3

t3.2 Results of LMM for decay rates on the surface zone and LMs for decay rates on the subsurt3.3 face zone and fungal biomass in both the surface and subsurface zones. Standardised effect t3.4 sizes (SES), and their standard errors (SEs) and $p$-values are shown. Significant variables t3.5 ( $\quad$ s .05) are highlighted in bold. et al., 2012; Zoppini et al., 2014). The fact that the subsurface zone maintains an important number of active microbial organisms during the non-flow periods could translate into maintaining decomposition, as our results show that the subsurface zone had more constant or stable environmental conditions than the surface zone, during flow cessation. In addition, as this zone remains saturated with water for longer periods (Martínez et al., 2015), it provides a habitat for benthic organisms that move vertically into the subsurface zone, and it is the major compartment of OM storage (Boulton et al., 1899; Grimm and Fisher, 1984). In addition, groundwater inputs and bank inflows can help to keep the subsurface zone saturated for longer (Boulton et al., 1998; Burrows et al., 2017).

\subsection{Effects of hydrological and environmental features on OM decomposi-} tion and the fungal community

Although our results clearly show effects of the number of non-flow days and the zone on OM decomposition and fungal biomass, our streams showed highly variable responses, mainly due to differences in the environmental features of each stream, as we hypothesised.

In the case of decay rates in the surface zone, we did not find that their magnitude depended on other measured environmental features. This could be due to environmental features such as SRP concentrations, which mainly affect the early stages, whereas the later stages are mainly dependent on hydrological conditions (Menéndez et al., 2011). Indeed, during the exploratory analysis, we found a positive correlation between the SRP and AFDM loss at t1 (i.e., after 90 days, data not shown). However, our analyses indicated that high SRP was linked to higher fungal biomass in the surface zone. Some studies have found that higher nutrient concentrations favour the growth of microbial decomposers and stimulate their activity up to a certain level (Sridhar et al., 2009; Suberkropp et al., 2010).

In the subsurface zone, our results suggest that microbial decomposition depends on the combined influence of hydrology and sediment

nutrient cycling during non-flow periods (Marxen et al., 2010; Steward

a)

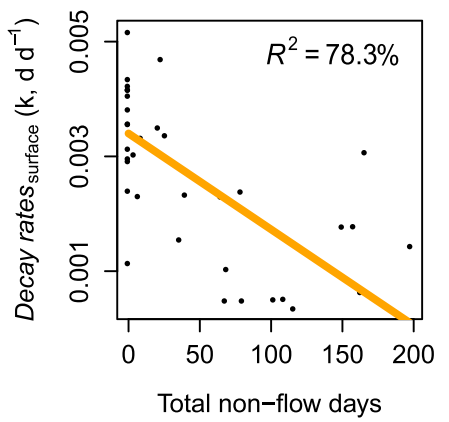

d)

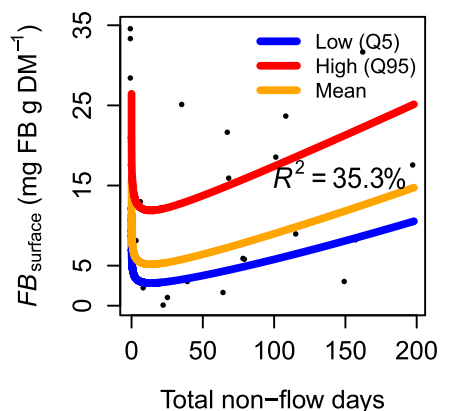

b)

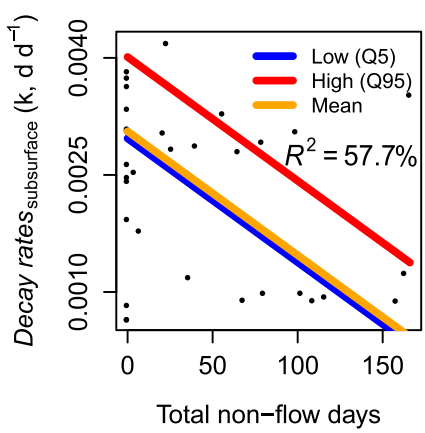

e)

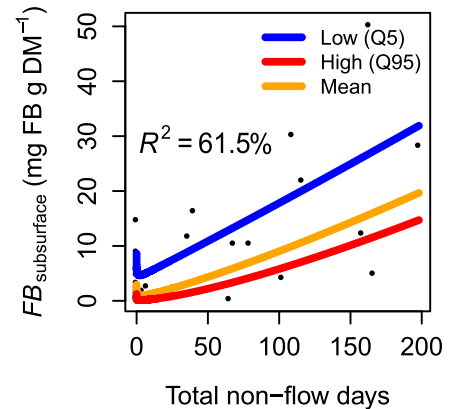

c)

Moisture content

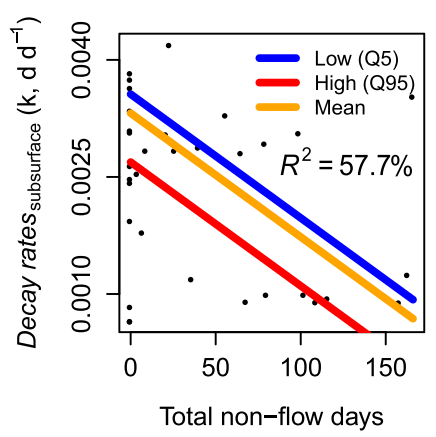

f) $\quad C: N$ ratios of sediment

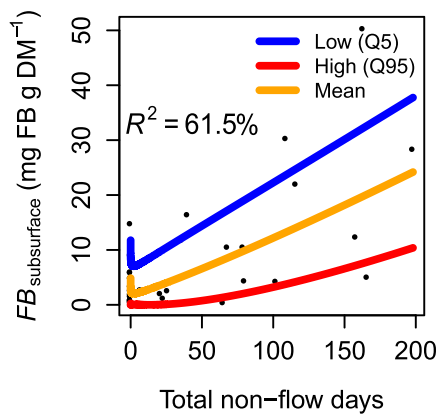

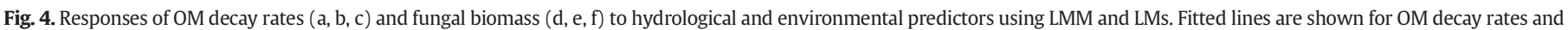

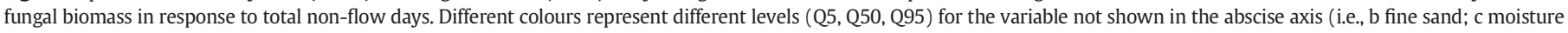

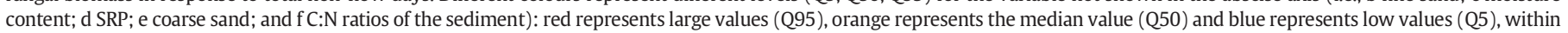
the data set. (For interpretation of the references to colour in this figure legend, the reader is referred to the web version of this article.) 
characteristics such as $\mathrm{C}: \mathrm{N}$ content, grain size and porosity (Artigas et al., 2008; Cornut et al., 2010; Medeiros et al., 2009; Mora-gómez et al., 2018). Fine sand can retain water for longer and thus could favour the growth of microbial decomposers (mainly bacteria), which translates into higher decay rates (Ghate and Sridhar, 2015), as we observed in this study.

Fungal biomass is negatively linked to coarse sand content, which enables better hydraulic and vertical connectivity (Arce et al., 2019). Nevertheless, when hydraulic connectivity disappears as flow ceases in the surface zone, water loss is faster with larger particle sizes, such as coarse sand, than with other sediments, such as fine sand (Mardhiah et al., 2014).

In our study, we also found that lower $\mathrm{C}: \mathrm{N}$ ratios in the sediment led to higher fungal biomass in the subsurface zone. This result could be due to the positive effect of nitrogen availability on microbial decomposer growth (Menéndez et al., 2011).

\section{Conclusions}

Our study shows how subsurface zones contribute to maintain microbial decomposition during non-flow periods in IRES, which could potentially affect ecosystem functioning, sediment food webs and $\mathrm{CO}_{2}$ emissions budgets. The levels of fungal biomass present in the $\mathrm{OM}$ in the subsurface sediment are higher than those present in the surface when dryness is severe. Environmental features such as SRP and sediment grain size modulate hydrological effects on decay rates and fungal biomass. These results provide a better understanding of how microbial decomposition may respond to the expected increase in the duration and severity of flow intermittency because of climate change.

Altogether, these findings indicate that dry streambeds must be considered to ensure the fluvial ecosystem functions carried out by sediment microbiota.

Supplementary data to this article can be found online at https://doi. org/10.1016/j.scitotenv.2019.135485.

\section{Declaration of competing interest}

All authors agree with the content of the manuscript and approve of its submission to Science of the Total Environment. The authors declare no conflict of interest.

\section{Acknowledgements}

We gratefully acknowledge the field survey assistance of Giulia Gionchetta and Miriam Colls. We would like to thank Sergi Sabater and the three anonymous reviewers for constructive suggestions on earlier versions of the manuscript.

The Ministry of Economy, Industry and Competitiveness of Spain (MINECO) funded this work through projects: CGL2014-58760-C3-1-R (FUNSTREAM) and CGL2017-88640-C2-2-R (SPACESTREAM).

Rebeca Arias-Real held a predoctoral grant BES-2015-073961 (MINECO, FPI). CG-C was supported by a "Juan de la CiervaFormación" research contract (MINECO, FJCI-2015-25785) and STREAMECO project (Biodiversity and ecosystem functioning under climate change: from the gene to the stream, POCI-01-0145-FEDER029505), funded by Fundação para a Ciência e a Tecnologia (Portugal).

\section{References}

Abril, M., Muñoz, I., Menéndez, M., 2016. Heterogeneity in leaf litter decomposition in a temporary Mediterranean stream during flow fragmentation. Sci. Total Environ. 553, 330-339. https://doi.org/10.1016/j.scitotenv.2016.02.082.

Akaike, 1973. Information theory and an extension of themaximum likelihood principle. In: Petrov, B.N. (Ed.), Proceedings of the Second International Symposium on Information Theory. Akad. Kiado, Budapest, pp. 267-281.

Arce, M.I., Mendoza-Lera, C., Almagro, M., Catalán, N., Romaní, A.M., Martí, E., Gómez, R., Bernal, S., Foulquier, A., Mutz, M., Marcé, R., Zoppini, A., Gionchetta, G., Weigelhofer, G., del Campo, R., Robinson, C.T., Gilmer, A., Rulik, M., Obrador, B., Shumilova, O.,
Zlatanović, S., Arnon, S., Baldrian, P., Singer, G., Datry, T., Skoulikidis, N., Tietjen, B., von Schiller, D., 2019. A conceptual framework for understanding the biogeochemistry of dry riverbeds through the lens of soil science. Earth-Science Rev 188, 441-453. https://doi.org/10.1016/j.earscirev.2018.12.001.

Arias-Real, R., Menéndez, M., Abril, M., Oliva, F., Muñoz, I., 2018. Quality and quantity of leaf litter: both are important for feeding preferences and growth of an aquatic shredder. PLoS One 13 (12), e0, 1-17. https://doi.org/10.1371/journal.pone.0208272.

Arroita, M., Aristi, I., Flores, L., Larrañaga, A., Díez, J., Mora, J., Romaní, A.M., Elosegi, A. 2012. The use of wooden sticks to assess stream ecosystem functioning: comparison with leaf breakdown rates. Sci. Total Environ. 440, 115-122. https://doi.org/10.1016/ j.scitotenv.2012.07.090.

Artigas, J., Romanı, A.M., Sabater, S., 2008. Effect of nutrients on the sporulation and diversity of aquatic hyphomycetes on submerged substrata in a Mediterranean stream. Aquat. Bot. 88, 32-38. https://doi.org/10.1016/j.aquabot.2007.08.005.

Barnard, R.L., Osborne, C.A., Firestone, M.K., 2015. Changing precipitation pattern alters soil microbial community response to wet-up under a Mediterranean-type climate. ISME J 9, 946-957. https://doi.org/10.1038/ismej.2014.192.

Blazewicz, S.T.J.B., Chwartz, E.G.S., Firestone, M.K., 2014. Growth and death of bacteria and fungi underlie rainfall-induced carbon dioxide pulses from seasonally dried soil. Ecology 95, 1162-1172. https://doi.org/10.1890/13-1031.1.

Boulton, A.A.J., Datry, T., Kasahara, T., Mutz, M., Jack, A., Boulton, A.J., Datry, T., Kasahara, T., Mutz, M., Stanford, J.A., 1899. Ecology and management of the hyporheic zone: stream - groundwater interactions of running waters and their floodplains. J. North Am. Benthol. Soc. 29, 26-40. https://doi.org/10.1899/08-017.1.

Boulton, A.J., Findlay, S., Marmonier, P., Stanley, E.H., Valett, H.M., 1998. The functional significance of the hyporheic zone in streams and rivers. Annu. Rev. Ecol. Syst. 29, 59-81.

Bruder, A., Chauvet, E., Gessner, M.O., 2011. Litter diversity, fungal decomposers and litter decomposition under simulated stream intermittency. Fuctional Ecol 25, 1269-1277. https://doi.org/10.1111/j.1365-2435.2011.01903.x.

Burrows, R.M., Rutlidge, H., Bond, N.R., Eberhard, S.M., Auhl, A., Andersen, M.S., Valdez, D.G., Kennard, M.J., 2017. High rates of organic carbon processing in the hyporheic zone of intermittent streams. Sci. Rep., 1-11 https://doi.org/10.1038/s41598-01712957-5.

Constantz, J., Stonestrom, D., Stewart, A.E., Smith, T.R., 2001. Analysis of streambed temperatures in ephemeral channels to determine streamflow frequency and duration. Water Resour. Res. 37, 317-328. https://doi.org/10.1029/2000WR900271|.

Cornut, J., Arnaud, E., Lambrigot, D., Marmonier, P., Chauvet, E., 2010. Early stages of leaf decomposition are mediated by aquatic fungi in the hyporheic zone of woodland streams. Freshw. Biol., 2541-2556 https://doi.org/10.1111/j.1365-2427.2010.02483. $\mathrm{X}$.

Cornut, J., Elger, A., Greugny, A., Bonnet, M., Chauvet, E., 2012. Coarse particulate organic matter in the interstitial zone of three French headwater streams. Ann. Limnol. - Int J. Limnol. 48, 303-313. https://doi.org/10.1051/limn/2012019.

Cornut, J., Chauvet, E., Mermillod-blondin, F., Assemat, F., Elger, A., 2014. Aquatic hyphomycete species are screened by the hyporheic zone of. $80,1949-1960$. https://doi. org/10.1128/AEM.03024-13.

Corti, R., Drummond, T.D.L., 2011. Natural variation in immersion and emersion affects breakdown and invertebrate colonization of leaf litter in a temporary river. Aquat Ecol. 73, 537-550. https://doi.org/10.1007/s00027-011-0216-5.

Costantini, M.L., Rossi, L., 2010. Species diversity and decomposition in laboratory aquatic systems: the role of species interactions. Freshw. Biol. 55, 2281-2295. https://doi.org/ 10.1111/j.1365-2427.2010.02433.x.

Datry, T., Claret, R.C.C., Philippe, M., 2011. Flow Intermittence Controls Leaf Litter Breakdown in a French Temporary Alluvial River: The '“Drying Memory"'. , pp. 471-483. https://doi.org/10.1007/s00027-011-0193-8.

Datry, T., Larned, S.T., Tockner, K., 2014. Intermittent rivers: a challenge for freshwater ecology. Bioscience 64, 229-235. https://doi.org/10.1093/biosci/bit027.

Datry, T., Singer, G., Sauquet, E., Jorda-Capdevila, D., Schiller, D. Von, Magand, C., Pa, P., Miliša, M., Acuña, V., Alves, M.H., Augeard, B., Brunke, M., Cid, N., Csabai, Z., England, J., Froebrich, J., Koundouri, P., Lamouroux, N., Martí, E., Morais, M., Munné, A., Pesic, V., Previši, A., Reynaud, A., Robinson, C., Sadler, J., Skoulikidis, N., Terrier, B., Tockner, K., Vesely, D., Zoppini, A., 2017. Science and Management of Intermittent Rivers and Ephemeral Streams ( SMIRES ). Res. Ideas Outcomes 3, e21774. https:// doi.org/10.3897/rio.3.e21774.

Datry, T., Foulquier, A., Corti, R., von Schiller, D., Tockner, K., Mendoza-Lera, C., Clément, J.C., Gessner, M.O., Moleón, M., Stubbington, R., Gücker, B., Albariño, R., Allen, D.C. Altermatt, F., Arce, M.I., Arnon, S., Banas, D., Banegas-Medina, A., Beller, E. Blanchette, M.L., Blanco-Libreros, J.F., Blessing, J.J., Boëchat, I.G., Boersma, K.S. Bogan, M.T., Bonada, N., Bond, N.R., Brintrup Barría, K.C., Bruder, A., Burrows, R.M., Cancellario, T., Canhoto, C., Carlson, S.M., Cauvy-Fraunié, S., Cid, N., Danger, M., de Freitas Terra, B., De Girolamo, A.M., de La Barra, E., del Campo, R., Diaz-Villanueva, V.D., Dyer, F., Elosegi, A., Faye, E., Febria, C., Four, B., Gafny, S., Ghate, S.D., Gómez, R., Gómez-Gener, L., Graça, M.A.S., Guareschi, S., Hoppeler, F., Hwan, J.L., Jones, J.I., Kubheka, S., Laini, A., Langhans, S.D., Leigh, C., Little, C.J., Lorenz, S., Marshall, J.C., Martín, E., McIntosh, A.R., Meyer, E.I., Miliša, M., Mlambo, M.C., Morais, M., Moya N., Negus, P.M., Niyogi, D.K., Papatheodoulou, A., Pardo, I., Pařil, P., Pauls, S.U., Pešić V., Polášek, M., Robinson, C.T., Rodríguez-Lozano, P., Rolls, R.J., Sánchez-Montoya, M.M., Savić, A., Shumilova, O., Sridhar, K.R., Steward, A.L., Storey, R., Taleb, A., Uzan, A., Vander Vorste, R., Waltham, N.J., Woelfle-Erskine, C., Zak, D., Zarfl, C., Zoppini, A. 2018. A global analysis of terrestrial plant litter dynamics in non-perennial waterways. Nat. Geosci. 11, 497-503. https://doi.org/10.1038/s41561-018-0134-4.

Duarte, S., Mora-Gómez, J., Romanı, A.M., 2017. Responses of microbial decomposers to drought in streams may depend on the environmental context. Environ. Microbiol. Rep. 9, 756-765. https://doi.org/10.1111/1758-2229.12592. 
Feld, C.K., Segurado, P., Gutiérrez-Cánovas, C., 2016. Analysing the impact of multiple stressors in aquatic biomonitoring data: a ' cookbook ' with applications in R. Sci. Total Environ. 573, 1320-1339. https://doi.org/10.1016/j.scitotenv.2016.06.243.

Follstad Shah, J.J., Kominoski, J.S., Ardón, M., Dodds, W.K., Gessner, M.O., Griffiths, N.A., Hawkins, C.P., Johnson, S.L., Lecerf, A., LeRoy, C.J., Manning, D.W.P., Rosemond, A.D. Sinsabaugh, R.L., Swan, C.M., Webster, J.R., Zeglin, L.H., 2017. Global synthesis of the temperature sensitivity of leaf litter breakdown in streams and rivers. Glob. Chang Biol. 23, 3064-3075. https://doi.org/10.1111/gcb.13609.

Foulquier, A., Artigas, J., Pesce, S., Datry, T., 2015. Drying responses of microbial litter decomposition and associated fungal and bacterial communities are not affected by emersion frequency. Freshw. Sci. 34, 1233-1244. https://doi.org/10.1086/682060.

Gessner, M.O., 2005. Ergosterol as a measure of fungal biomass. Methods to Study Litter Decomposition: A Practical Guide, pp. 231-236. https://doi.org/10.1007/1-40203466-0_25.

Gessner, M.O., Chauvet, E., 1993. Ergosterol-to-biomass conversion factors for aquatic hyphomycetes. Appl. Environ. Microbiol. 59, 502-507.

Gessner, M.O., Chauvet, E., 1994. Importance of stream microfungi in controlling breakdown rates of leaf litter. Ecology 75, 1807-1817. https://doi.org/10.2307/1939639.

Gessner, M.O., Chauvet, E., Dobson, M., 1999. A perspective on leaf litter breakdown in streams. Oikos 85, 377-384. https://doi.org/10.2307/3546505.

Gessner, M.O., Swan, C.M., Dang, C.K., McKie, B.G., Bardgett, R.D., Wall, D.H. Hättenschwiler, S., 2010. Diversity meets decomposition. Trends Ecol. Evol. 25, 372-380. https://doi.org/10.1016/j.tree.2010.01.010.

Ghate, S.D., Sridhar, K.R., 2015. Diversity of aquatic hyphomycetes in streambed sediments of temporary streamlets of Southwest India. Fungal Ecol. 14, 53-61. https:/ doi.org/10.1016/j.funeco.2014.11.005.

Gionchetta, G., Oliva, F., Menéndez, M., Lopez, P., Anna, L., 2019. Key role of streambed moisture and flash storms for microbial resistance and resilience to long-term drought. Freshw. Biol. 64, 306-322. https://doi.org/10.1111/fwb.13218.

Gonçalves, A.L., Chauvet, E., Bärlocher, F., Graça, M.A.S., Canhoto, C., 2014. Top-down and bottom-up control of litter decomposers in streams. Freshw. Biol. 59, 2172-2182. https://doi.org/10.1111/fwb.12420.

Gonçalves, A.L., Lírio, A.V., Graça, M.A.S., Canhoto, C., 2016. Fungal species diversity affects leaf decomposition after drought. Int. Rev. Hydrobiol. 101, 78-86. https://doi.org/ 10.1002/iroh.201501817.

Graça, M.A.S., Cressa, C., Gessner, M.O., Feio, M.J., Callies, K.A., Barrios, C., 2001. Food quality, feeding preferences, survival and growth of shredders from temperate and tropical streams. Freshw. Biol. 46, 947-957. https://doi.org/10.1046/j.13652427.2001.00729.x.

Grimm, N.B., Fisher, S., 1984. Exchange between interstitial and surface water: implications for stream metabolism and nutrient cycling. Hydrobiologia 111, 219. https:// doi.org/10.1007/BF00007202.

Krauss, Gudrun, Schlosser, D., Wesenberg, D., Gerd-joachim, Krauss, Sol, M., Bärlocher, F. 2011. Fungi in freshwaters: ecology, physiology and biochemical potential. FEMS Microbiol. Rev. 35, 620-651. https://doi.org/10.1111/j.1574-6976.2011.00266.x.

Harjung, A., Perujo, N., Butturini, A., Romaní, A.M., Sabater, F., 2019. Responses of microbial activity in hyporheic pore water to biogeochemical changes in a drying headwater stream. Freshw. Biol. https://doi.org/10.1111/fwb.13258 fwb.13258.

Hoffman, G.E., Schadt, E.E., 2016. variancePartition: interpreting drivers of variation in complex gene expression studies. BMC Bioinformatics 17, 483. https://doi.org/ 10.1186/s12859-016-1323-z.

Kuehn, K.A., 2016. Lentic and lotic habitats as templets for fungal communities: traits, adaptations, and their significance to litter decomposition within freshwater ecosystems. Fungal Ecol. 19, 135-154. https://doi.org/10.1016/j.funeco.2015.09.009.

Lake, P.S., 2003. Ecological effects of perturbation by drought in flowing waters. Freshw. Biol. 48, 1161-1172. https://doi.org/10.1046/j.1365-2427.2003.01086.x|.

Larned, S.T., Datry, T., Arscott, D.B., Tockner, K., 2010. Emerging concepts in temporaryriver ecology. Freshw. Biol. 55, 717-738. https://doi.org/10.1111/j.13652427.2009.02322.x.

Mardhiah, U., Caruso, T., Gurnell, A., Rillig, M.C., 2014. Soil Biology \&amp; Biochemistry Just a matter of time : fungi and roots significantly and rapidly aggregate soil ove four decades along the Tagliamento River , NE Italy. Soil Biol. Biochem. 75, 133-142. https://doi.org/10.1016/j.soilbio.2014.04.012.

Martínez, A., Pérez, J., Molinero, J., Sagarduy, M., Pozo, J., 2015. Effects of flow scarcity on leaf-litter processing under oceanic climate conditions in calcareous streams. Sci. Total Environ. 503-504, 251-257. https://doi.org/10.1016/j.scitotenv.2014.06.018.

Marxen, J., Zoppini, A., Wilczek, S., 2010. Microbial communities in streambed sediments recovering from desiccation. FEMS Microbiol. Ecol. 71, 374-386. https://doi.org/ 10.1111/j.1574-6941.2009.00819.x

Medeiros, A.O., Pascoal, C., Graça, M.A.S., 2009. Diversity and activity of aquatic fungi under low oxygen conditions. Freshw. Biol. 54, 142-149. https://doi.org/10.1111/ j.1365-2427.2008.02101.x.
Menéndez, M., Descals, E., Riera, T., Moya, O., 2011. Leaf litter breakdown in Mediterranean streams: effect of dissolved inorganic nutrients. Hydrobiologia 669, 143-155. https://doi.org/10.1007/s10750-011-0657-9.

Mora-gómez, J., Cássio, F., Pascoal, C., Romaní, A.M., 2018. Microbial decomposition is highly sensitive to leaf litter emersion in a permanent temperate stream. Sci. Total Environ. 621, 486-496. https://doi.org/10.1016/j.scitotenv.2017.11.055.

Murphy, J., Riley, J.P., 1962. A modified single solution method for the determination of phosphate in natural waters. Anal. Chim. Acta 27, 31-36. https://doi.org/10.1016/ S0003-2670(00)88444-5.

Mustonen, K.R., Mykrä, H., Louhi, P., Markkola, A., Tolkkinen, M., Huusko, A., Alioravainen, N., Lehtinen, S., Muotka, T., 2016. Sediments and flow have mainly independent effects on multitrophic stream communities and ecosystem functions. Ecol. Appl. 26, 2116-2129. https://doi.org/10.1890/15-1841.1/suppinfo.

Petersen, R., Cummins, K., 1974. Leaf processing in a woodland stream. Freshw. Biol. 4, 343-368. https://doi.org/10.1111/j.1365-2427.1974.tb00103.x.

Pinheiro, J., Bates, D., DebRoy, S., Sarkar, D., R Core Team, 2017. Nlme: Linear and Nonlinear Mixed Effects Models_. R Packag. Version 3.1-131 2017.

Pinna, M., Basset, A., 2004. Summer drought disturbance on plant detritus decomposition processes in three River Tirso (Sardinia, Italy) sub-basins. Hydrobiologia 522, 311-319. https://doi.org/10.1023/B:HYDR.0000029984.93471.b5.

Pohlon, E., Fandino, A.O., Marxen, J., 2013. Bacterial community composition and extracellular enzyme activity in temperate streambed sediment during drying and rewetting. PLoS One 8, e83365. https://doi.org/10.1371/journal.pone.0083365.

R Development Core Team, R, 2011. R: A Language and Environment for Statistical Computing. R Foundation for Statistical Computing https://doi.org/10.1007/978-3-54074686-7.

Reardon, J., Company, C.M., Valley, S., 1969. United States Patent Office 3-6.

Sanpera-Calbet, I., Acuña, V., Butturini, A., Marcé, R., Muñoz, I., 2016. El Niño southern oscillation and seasonal drought drive riparian input dynamics in a Mediterranean stream. Limnol. Oceanogr. 61, 214-226. https://doi.org/10.1002/lno.10211.

Scott, S., Zhang, Y., 2012. Contrasting effects of sand burial and exposure on invertebrate colonization of leaves. Am. Midl. Nat. 167, 68-78. https://doi.org/10.1674/00030031-167.1.68.

Solagaistua, L., Arroita, M., Aristi, I., Larrañaga, A., Elosegi, A., 2016. Changes in discharge affect more surface than subsurface breakdown of organic matter in a mountain stream. Mar. Freshw. Res. 67, 1826-1834.

Sridhar, K.R., Duarte, S., Cássio, F., Pascoal, C., 2009. The role of early fungal colonizers in leaf-litter decomposition in Portuguese streams impacted by agricultural runoff. Int. Rev. Hydrobiol. (4), 399-409 https://doi.org/10.1002/iroh.200811154.

Steward, A.L., von Schiller, D., Tockner, K., Marshall, J.C., Bunn, S.E., 2012. When the river runs dry: human and ecological values of dry riverbeds. Front. Ecol. Environ. 10, 202-209. https://doi.org/10.1890/110136.

Storey, R.G., Fulthorpe, R.R., Williams, D.D., 1999. Perspectives and predictions on the microbial ecology of the hyporheic zone. Freshw. Biol. 41, 119-130. https://doi.org/ 10.1046/j.1365-2427.1999.00377.x|

Stout, R.J., 1989. Effects of condensed tannins on leaf processing in mid-latitude and tropical streams: a theoretical approach. Can. J. Fish. Aquat. Sci. 46, 1097-1106. https:// doi.org/10.1139/f89-142.

Stubbington, R., 2012. The hyporheic zone as an invertebrate refuge: a review of variability in space , time , taxa and behaviour. Mar. Freshw. Res. 63, 293-311. https://doi. org/10.1071/MF11196.

Suberkropp, K., Arsuffi, T.L., Anderson, J.P., 1983. Comparison of degradative ability, enzymatic activity, and palatability of aquatic hyphomycetes grown on leaf litter. Appl. Environ. Microbiol. 46, 237-244.

Suberkropp, K., Gulis, V., Rosemond, A.D., Benstead, J.P., 2010. Ecosystem and physiological scales of microbial responses to nutrients in a detritus-based stream : results of a 5-year continuous enrichment. Limnol. Oceanogr. 55, 149-160.

Zoppini, A., Ademollo, N., Amal, S., Casella, P., Patrolecco, L., Polesello, S., 2014. Organic priority substances and microbial processes in river sediments subject to contrasting hydrological conditions. Sci. Total Environ. 484, 74-83. https://doi.org/10.1016/j. scitotenv.2014.03.019.

Zuur, A.F., Leno, E.N., Walker, N., Saveliev, A.A., Smith, G.M., 2009. Mixed Effects Models and Extensions in Ecology with R. Springer https://doi.org/10.1007/978-0-38787458-6.

Zuur, A.F., Ieno, E.N., Elphick, C.S., 2010. A protocol for data exploration to avoid common statistical problems. Methods Ecol. Evol. 1, 3-14. https://doi.org/10.1111/j.2041210X.2009.00001.X 